\title{
ヒツジのルーメン内飼料中長鎖脂肪酸に及ぼす濃厚飼料と 粗飼料比の影響
}

\author{
佐々木 啓・堀口健一 ${ }^{1} \cdot$ 高橋敏能 \\ 岩手大学大学院連合農学研究科, 盛岡市 020-8550 \\ ${ }^{1}$ 山形大学農学部, 鶴岡市 997-8555 \\ (1999.10.6 受付, 受理2000.4.21)
}

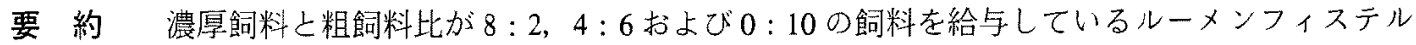
装着ヒッジを用い，給与飼料と同じ飼料をナイロンバック法で培養し，その残㵑の遊離脂肪酸（FFA） の割合之総脂肪酸 (TFA) 㧍よび FFA 組成の経時変化について調べた. 培養残渣の TFA 含量に上める FFA 含量の割合は, 粗飼料割合の増加にともなって高く推移した.TFAおよび FFAともに, オレイン 酸 (以下 $\mathrm{C}_{18: 1}$ ) とリノール酸 (以下 $\mathrm{C}_{18: 2}$ ) が濃厚飼料割合の增加にしたがって高く, ステアリン酸（以 下 $\mathrm{C}_{18: 0}$ ）は低く推移した。 また，培養 48 時間後のFFAでは，濃厚飼料：粗飼料比が $4: 6$ および $0: 10$ の飼料に存在する $\mathrm{C}_{18}$ の不飽和脂肪酸（USFA）はほとんよ゙みられなかった。これらの結果から，微生物 による飼料中脂質の加水分解は，濃厚飼料を培養したときに比べ粗飼料のみ培養したときに速やかに行 われると考劣られた。 また，濃厚飼料割合が高いほど，水素添加の中間物質である $\mathrm{C}_{18: 1}$ が蓄積され， FFA として存在する $\mathrm{C}_{18}$ のUSFA への水素添加は濃厚飼料：粗飼料比が $4: 6$ および $0: 10$ の飼料で促 進されると推察された。
\end{abstract}

日本畜産学会報，71 (9)：J323-J330, 2000

反妿動物のルーメン内における脂質代謝に関しては， 微生物に上る飼料中脂質の加水分解とUSFA への水素 添加が行われるこよが知られている(2). 飼料中脂質のエ ステル型脂肪酸はただちに徽生物のリパーゼにより加水 分解され，FFA 吕生成される。これら FFAのうち二重 結合を持つUSFA 流，㧤本に細菌に上り生産される酵素

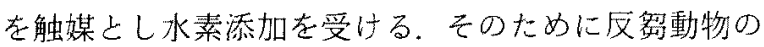
ルーメン内には高濃度の FFA が存在し, その FFA 生成 量が微生物の瀻維分解に対して抑制的に働くことが知ら れている11.

一方，反矣動物において，濃厚飼料之粗飼料の比率 (以下, 濃粗比亡略称する) の変化は, ルーメン内微生物 濃度 ${ }^{33}$ と揮発性脂肪酸の産生量 ${ }^{22}$ お。よび比率 ${ }^{18,27)}$ に影響 を及舛すことが知られている。したがって，微生物によ る加水分解作用とUSFA 八の水素添加に利用される水 素産生量む異なり，濃粗比の变化がルーメン内脂質代謝 に影響を及ぼすと考えら扎る。さきに筆者らは，濃粗比 の異なる飼料をヒッジに給与したとき，ルーメン内液の 脂質の加水分解之長鎖脂肪酸八の水素添加の様相を報告
した233.しかしながら、ルーメン内細菌は遊離型と固形 性飼料固着型とが分布し，その多くは固形性飼料固着細 菌であること(9)功知られている。 また，Bauchart らやや O'Kelly 々 Spiers ${ }^{20}$ はルーメン内容物の固層付着細菌お よび液層中細菌の脂質含量は固層付着細菌の方が多く, 飼料中脂質の摄取能や脂質合成において屯固層付着細菌 が多く寄与していることを報告した，また，Hawke は， ルーメン内液中に出現する脂肪酸上りも飼料片に存在す る脂肪酸に対する細菌の水素添加能が高いことを報告し た。 そこで本試験では，濃粗比の違いが飼料片中に存在 する長鎖脂肪酸の量とその組成に及ぼす影響を調査する ための一環として，濃粗比の異なる飼料を給与したヒッ ジを用い，ナイロンバック法による残渣の TFA と FFA の消長について検討した。

\section{材料および方法}

\section{1）供試動物，飼養管理および給与試験方法}

供試動物はルーメンフィステル装着ヒツジ３頭を用い た。飼料は，濃厚飼料（日本農産工業株式会社，肉用牛

連絡者：佐々木 啓（fax : 023-623-0790, e-mail : hirari@me.neweb.ne.jp）

Anim. Sci. J. 71 (9) : J323-J330, 2000 
佐々太・堀门・高橋

Table 1. Chemical components of experimental diets ( $\%$ of DM)

\begin{tabular}{lccc}
\hline \multirow{2}{*}{ Components } & \multicolumn{3}{c}{ Concentrate : Roughage $^{1}$} \\
\cline { 2 - 4 } & $8: 2$ & $4: 6$ & $0: 10$ \\
\hline Crude protein & 14.2 & 9.6 & 5.1 \\
OCC $^{2}$ & 59.5 & 41.7 & 24.5 \\
OCW $^{3}$ & 33.2 & 52.0 & 70.1 \\
Crude ash $_{\text {Total lipid }}^{4}$ & 7.3 & 6.3 & 5.4 \\
Total fatty acid & 4.9 & 3.2 & 1.6 \\
\hline
\end{tabular}

${ }^{1}$ Calculated on dry matter basis.

${ }^{2}$ Organic cellular content.

${ }^{3}$ Organic cell wall.

${ }^{4}$ Extracted with chloroform-methanol, by Folchs'method.

Table 2. Fatty acid compositions of experimental diets ( $\%$ of TFA)

\begin{tabular}{lrrr}
\hline \multirow{2}{*}{ Fatty acids } & \multicolumn{3}{c}{ Concentrate : Roughage } \\
\cline { 2 - 4 } & $8: 2$ & $4: 6$ & $0: 10$ \\
\hline $\mathrm{C}_{14: 0}{ }^{1}$ & 0.4 & 0.9 & 4.5 \\
$\mathrm{C}_{16: 0}$ & 17.0 & 19.7 & 38.3 \\
$\mathrm{C}_{16: 1}$ & 0.5 & 0.6 & 1.4 \\
$\mathrm{C}_{18: 0}$ & 3.3 & 4.6 & 14.0 \\
$\mathrm{C}_{18: 1}$ & 30.3 & 28.3 & 14.6 \\
$\mathrm{C}_{18: 2}$ & 47.4 & 43.2 & 14.5 \\
$\mathrm{C}_{18: 3}$ & 0.2 & 0.9 & 5.5 \\
Other fatty acids & 2.9 & 3.0 & 3.6 \\
SFA $^{2}$ & & & \\
USFA $^{3}$ & 32.0 & 34.6 & 49.5 \\
\hline
\end{tabular}

${ }^{1}$ Number of carbon atoms in fatty acids : number of double bonds.

${ }^{2}$ Saturated fatty acid.

${ }^{3}$ Unsaturated fatty acid.

配合飼料ダイナビーフ）と粗飼料（イタリアンライグラ 不牧乾草, 切断長 $2 \mathrm{~cm}$ ) 在 $8: 2$ (濃厚飼料多給与), 4 : 6(中間配合) 抢よび 0:10 (粗飼料多給与) の3 段階の 給与比率しして，それぞ乾物で体重の $2 \%$ 量を 1 日 1 回 (千前 9 時) 給与した。水は自由捸取とした。るれぞれ の給与飼料の化学組成および脂肪酸組成は表 1 および 2 に示すとおりであった。 また，給与試験は，各飼料の馴 致期間を 14 日間とし，1期 16 日間の $3 \times 3$ のラテン万格 法で実施した。

\section{2）ルーメン内分解性の測定}

ナイロンバック法によりルーメン内に打ける給与飼料 の乾物の分解性について測定した。すすなわち，給与飼料 と同じ濃厚飼料上粗飼料を $2 \mathrm{~mm}$ に粉砕し $1.5 \mathrm{~g}$ を個々 にナイロンバックに入れた．濃厚飼料多給与と中間配合 のヒツジには濃厚飼料が入ったナイロンバックと粗飼料 の入ったナイロンバックの両方を，粗飼料多給与のヒッ ジには粗飼料が入ったナイロンバックのみを飼料給与時 にフィステルよりルーメンに投入し $1.5,3 ， 6 ， 12,18$, 24 扰よび 48 時間培善した。濃厚飼料と粗飼料の分解率 を求め, 濃粗比 $8: 2,4: 6$ および $0: 10$ の比率に換算 し，各給与飼料の分解率とした。ささらに，各培養時間で 得られた乾物の分解率を, $\mathrm{p}=\mathrm{a}+\mathrm{b}\left(1-\mathrm{e}^{-\mathrm{ct}}\right)^{17)}$ の式に当 てはめ，可溶性画分 $(\mathrm{a}, \%)$ ，分解性画分 $(\mathrm{b}, \%)$ ，分 解速度 $(\mathrm{c}, \% / \mathrm{h})$ 在求めた。

\section{3）分析の方法}

飼料中の水分, 粗タンパク質扔よび粗灰分の定量は常 法 ${ }^{8}$ 15) により, 細胞内容物（OCC）上細胞壁構成物質 (OCW) は，アミラーゼ・プロテアーゼ混合酵素分析 法 ${ }^{14)}$ により測定しだ.ナイロンバック法により得られた 残渣は, $60^{\circ} \mathrm{C}$ で 48 時間乾燥した㣪，試料の一部を乾熱 $\left(135^{\circ} \mathrm{C}\right.$ で 2 時間) 乾燥法 $\left.{ }^{8}\right) に よ り$ 乾物の重量を測定し た。 また，脂質の分析試料は試料中脂質の反応性を極力 抑えるため，加熱好理を行わず，窒素ガスを噴霧し密閉 し $-20^{\circ} \mathrm{C}$ で 24 時間凍結した後, 暗所で倲結乾燥処理を 行ったあのを用いた．脂質の抽出はFolch らの方法2゙に より, FFAの分離よガスクロマトグラフィーによる各 脂肪酸の分離定量は, さきに報告した方法 ${ }^{23)}$ と同様とし t.

\section{4) 統計処理}

乾物の分解性を表す各パラメーターの検定は, $\mathrm{SAS}^{9)}$ のANOVA プログラムによる多重検定を行った。 また， TFA およびFFAの総量とTFAおよびFFA 組成中の 各脂肪酸については，GLM プログラムにより，飼料よ 時間の 2 元配置による分散分析を行い，それらにおける 有意性を検定した。

\section{結果および考察}

表 2 に各飼料の脂肪酸組成を示した。本試験で用いた 濃厚飼料はトゥモロコシ，マイロおよび大麦なよ゙の嵘類 主体の原材料加ら構成されているため，濃厚飼料の配合 割合を高めるにともなって $\mathrm{C}_{18: 1}$ および $\mathrm{C}_{18: 2}$ からなる USFA を多く含む脂肪酸組成であったままた，濃厚飼料 とは逆に，粗飼料の配合割合を高めるによもなってパル ミチン酸（以下 $\mathrm{C}_{16: 0}$ ）执よび $\mathrm{C}_{18: 0}$ の飽和脂肪酸の割合 


\section{ルーメン内飼料中脂肪酸の変化}

Table 3. Ruminal degradation characteristics of dry matter of experimental diets (Means of three sheep $\pm \mathrm{SD}$ )

\begin{tabular}{crrr}
\hline \multirow{2}{*}{ Item } & \multicolumn{3}{c}{ Concentrate : Roughage } \\
\cline { 2 - 4 } & \multicolumn{1}{c}{$8: 2$} & \multicolumn{1}{c}{$4: 6$} & $0: 10$ \\
\hline $\mathrm{a}(\%)^{!}$ & $22.7^{\mathrm{A}} \pm 0.3$ & $22.1^{\mathrm{A}} \pm 0.9$ & $14.5^{\mathrm{B}} \pm 1.5$ \\
$\mathrm{~b}(\%)^{2}$ & $49.3^{\mathrm{A}} \pm 5.2$ & $48.5^{\mathrm{A}} \pm 3.9$ & $34.9^{\mathrm{B}} \pm 2.4$ \\
$\mathrm{c}(\% / \mathrm{h})^{3}$ & $3.2^{\mathrm{B}} \pm 0.3$ & $3.0^{\mathrm{B}} \pm 1.0$ & $7.3^{\mathrm{A}} \pm 0.7$ \\
\hline
\end{tabular}

${ }^{1}$ Soluble fraction.

${ }^{2}$ Insoluble but degradable fraction.

${ }^{3}$ Rate of degradation.

$A, B$ : Mean values in same row with different superscripts differ significantly $(\mathbf{P}<0.05)$.

\section{が増加した。}

表 3 に，各配合比率の乾物のルーメン内分解性を示す

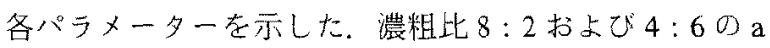
とbの值は，粗飼料単体上り西有意に高加った（ $\mathrm{P}<$ 0.05). また， $\mathrm{a}$ 值と $\mathrm{b}$ 值の合量であるルーメン内最大分 解率 $(\%)$ は，濃粗比 $8: 2 ， 4: 6$ および $0: 10$ で，それ ぞれ 72.0，70.6 扝よび 49.4であり，濃厚飼料を配合した とき高い值を示した。濃厚飼料を多給することにより ルーメン内の微生物濃度や数か増加したり，その種類が 変化したり寸るこしが報告されている3.16,23)。また，ルー メン内に拈いて易発酵性上考えられる OCC $(\%)$ は，濃 粗比 $8: 2,4: 6$ および 0:10でそれぞれ $59.5,41.7$ およ び 24.5 と濃厚飼料を配合したとき增加する（表 1)こと 加，濃厚飼料赽併用した場合，飼料の分解性む高く， 微生物による飼料の分解が活発に行われるものと考えら れた。

図 1 に，培養残渣中の TFA 含量の経時変化について 示した。 TFA 含量を各濃粗比間で比較すると, 濃厚飼料 の多給に上屯なってその含量は多く $(\mathbf{P}<0.01)$ 推移し た，培養時間の変化に坊いて有意な差ししては認められ なかったが，TFA 含量はいずれの飼料であ培養前より 屯 48 時間培養後のTFA 含量の方が高い傾向を示した。

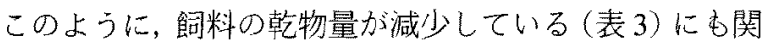
わらず培戋渣中の TFA 含量が減少しないことから， 飼料由来の総脂肪酸は，ルーメン内において餉料片中に 多く付着しているか残存していると考えられた。

飼料中の脂質にはFFA が含まれるが，その含量は少 量であり，飼料中の脂質を構成する脂肪酸の大半は糖脂 質などのエステル型脂肪酸であること 263 が知られてい る。これらエステル結合を有する脂肪酸は，ルーメン内 に入るとおちに細囷の細胞外酵素として合成されるり

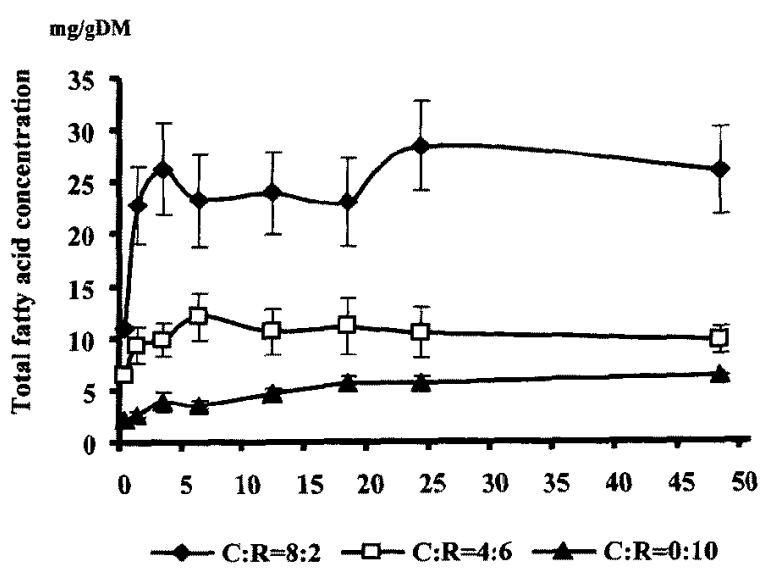

Fig. 1. Change in concentration of total fatty acids in residue by nylon bag method with different ratios of concentrate $(C)$ and roughage $(R)$.

Differences were significant $(\mathrm{P}<0.01)$ in diet, not significant in time and diet $\times$ time $(P \geqq 0.05)$.

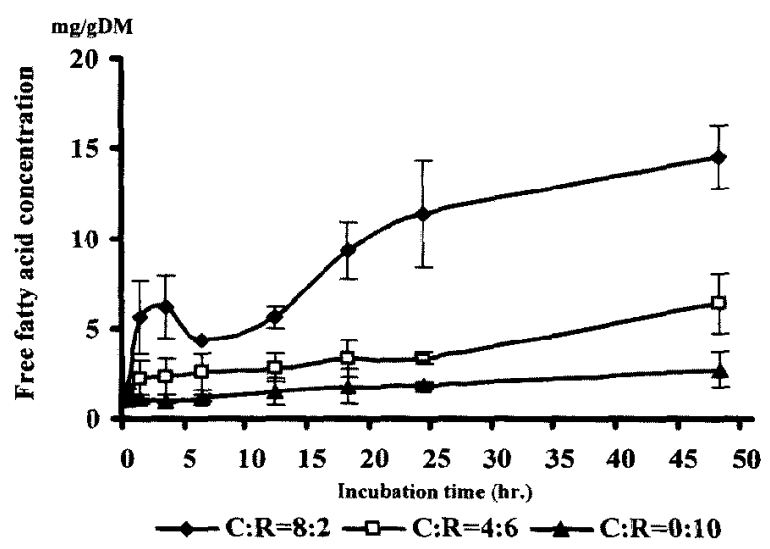

Fig. 2. Change in concentration of free fatty acids in residue by nylon bag method with different ratios of concentrate (C) and roughage ( $\mathrm{R}$ ).

Differences were significant $(P<0.01)$ in diet and time, not significant in time and diet $\times$ time $(P \geqq 0.05)$.

パーゼにより加水分解 されれ，不撂化物之FFA が生成 さ机る。ルーメン内で生成されたFFAのうちUSFA は, 微生物により水素添加され飽和脂肪酸へ上変換され $3^{25,26)}$.

図 2 に，培養残渣中のFFA 含量の経時変化について 示した。いずれの濃粗比において李培養前のFFA 含量 （mg/gDM）は，1.0～1.6と低加た。このことは，分析 試料の処理に打いて脂質構成の变化が少なかったことを

Anim. Sci. J. 71 (9) : J323-J330, 2000 
佐々木・堀口・高橋

示すものと考えられた．また，先に述べたように飼料に 含まれる脂肪酸は，そのほとんどがエステル結合を有す る脂肪酸であることが示される.FFA 含量を各濃粗比 間で比較すると，いず机の培養時間でもその值は濃厚飼

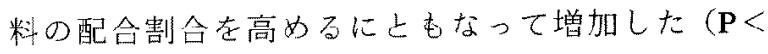
0.01). また, 培養 48 時間目の FFA 含量は, $2.7 \sim 14.5$ $\mathrm{mg} / \mathrm{gDM}$ 上，培養前よりもFFA 含量が增加した（ $\mathbf{P}<$ 0.01).このことから、いずれの濃粗比でむ微生物による 飼料中脂梊の加水分解が活発に行われ，FFAの量は飼 料中の脂肪酸含量が高いはど多く生成されることが示さ れた。

図 3 に，培養 48 時間までのナイロンバック法から得 ら机た残渣の TFAに占める FFA の比率（以下 FFA 比 上記す）の経時変化について示した，培養 1.5 時間後の 残渣の FFA 比（\%) は濃粗比 $8: 2,4: 6$ および0: 10 においてそ扎ぞれ 17.7，25.2 およよ゙ 28.4であったのに 対し，培養 48 時間後にはそれぞれ $44.9 ， 53.4$ および 52.4 に增加した $(\mathbf{P}<0.01)$.この FFA 比は微生物による エステル型脂肪酸の相対的な加水分解率を示す指標とな り得る23) と考えられ，いずれの濃粗比でも微生物による 脂質の加水分解が活発に行われたことを示す。また，

FFA 比の平均值（\%; 培養 48 時間までの値の平均, 以 下同じ）を各飼料間で比較すると, 濃粗比 $8: 2,4: 6$ お よび 0：10において，それぞれ 27.5，33.9および 41.9 で あり, 粗飼料の配合割合を高めるにとむなって増加した $(\mathbf{P}<0.01)$.このことは, 飼料中脂質含量が少ない濃粗比 $0: 10$ において相対的な脂質の加水分解が促進されたこ とを示すものであろう。この濃粗比間に扔ける FFA 比 の差は，培養 1.5 18 時間にかけて濃粗比間で顕著に現 れ，粗飼料割合の增加にともなって高い傾向を示し，培 養 24〜48 時間目にかけて，濃粗比間における大きな差 はみられなかった。 Noble ら201はインビトロ試験に扔い て, ルーメン内容液に異なる量のトリリノールを添加し たところ, 添加量功多いほど FFAの生成速度は緩徐で あり，添加したトリリノールすべてが糖質と FFAに加 水分解されなかったことを報告した。これらのことか ら，飼料中脂質含量が少ない粗飼料のみ培養したとき微 生物に上る脂質の加水分解が速や加に行われ，濃厚飼料 の配合にともない飼料中脂質含量が増加すると脂質の加 水分解速度は緩慢になると考えられた。

図4に,ナイロンバック法による培養残渣の主要脂肪 酸である $\mathrm{C}_{16: 0}$ と $\mathrm{C}_{18}$ の TFA 組成の経洔変化を示した。 飼料間で比較すると, リノレン酸 (以下 $\mathrm{C}_{18: 3}$ ) を除くす べての脂肪酸の組成比に有意な差が認められた。また， 培養時間の経過とともにすへてて脂肪酸の組成比に変化

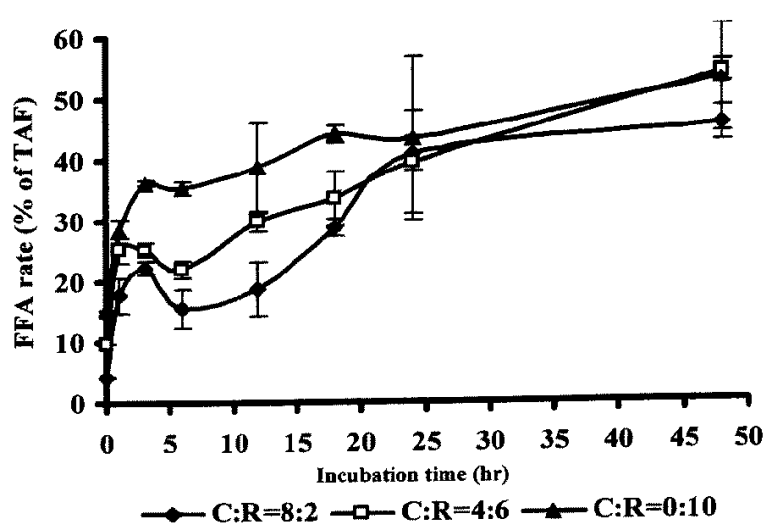

Fig. 3. Change in ratio of free fatty acids (FFA) to total fatty acids (TFA) in residue by nylon bag method with different ratios of concentrate $(\mathrm{C})$ and roughage (R).

Differences were significant $(P<0.01)$ in diet and time, not significant in time and $\operatorname{diet} \times$ time $(\mathrm{P} \geqq 0.05)$.

が認められた．各脂肪酸を時間による変化でみる上， $\mathrm{C}_{18: 0}$ は，いずれの飼料でも培養前より李培養 48 時間後 の組成比のほうが高加った（P<0.05）。このことは，前 述の上うに飼料中の $\mathrm{C}_{18}$ のUSFA が微生物によって水素 添加され，最終産物としての $\mathrm{C}_{18: 0}$ へと変換されたこと を示す。また， $\mathrm{C}_{18: 1}$ は，いずれの飼料でも培養前と培養 48 時間後之をくらべると，その組成比は減少した（P< $0.05)$ が, 濃粗比 $8: 2$ および $4: 6$ では, 培養前に $\mathrm{C}_{18: 1}$ の組成比 (\%) が 30.9 および 29.3 であったのに対し，培 養 48 時間後には 27.0 抢よび 24.0 と, 組成比の減少率 （\%）はそれぞ机12.6 および18.1であった。これに対 し，粗飼料のみ培養した上き，培養前の $\mathrm{C}_{18: 1}$ の組成比 が $16.8 \%$ であったが，培養 1.5 時間目には $\mathrm{C}_{18: 2}$ から水 素添加されたと考元られる $\mathrm{C}_{18: 1}$ が $26.7 \%$ に增加した。 この $\mathrm{C}_{18: 1}$ は，培養 48 時間後には $13.1 \%$ 上減少してお り，培養前之 48 時間後之の減少率は $2.4 \%$ と僅少であっ たが，培養 1.5 時間後からの減少率は $50.9 \%$ に及んだ。

これらのことは，飼料元来の二重結合を 1 つ以上有する $\mathrm{C}_{18}$ の脂肪酸含量が多い濃粗比 $8: 2$ および $4: 6$ におい て $\mathrm{C}_{18: 1}$ から $\mathrm{C}_{18: 0}$ への変換速度が粗飼料のみ培養した ときにくらべ緩慢であることを示す，また， $\mathrm{C}_{18: 2}$ は，い ずれの飼料であ培養前と培養 48 時間目とをくらべると 減少 $(\mathbf{P}<0.05)$ しており，培養前加ら培養 48 時間目ま での組成比の減少率（\%) は濃粗比 $8: 2,4: 6$ 拉よび 0 : 10 でそれぞれ 57.3, 84.6 および 71.3 であり, 濃粗比 4 ： 6 で最も高かった。飼料中 USFAの飽和化に利用される 
ルーメン内飼料中脂肪酸の变化
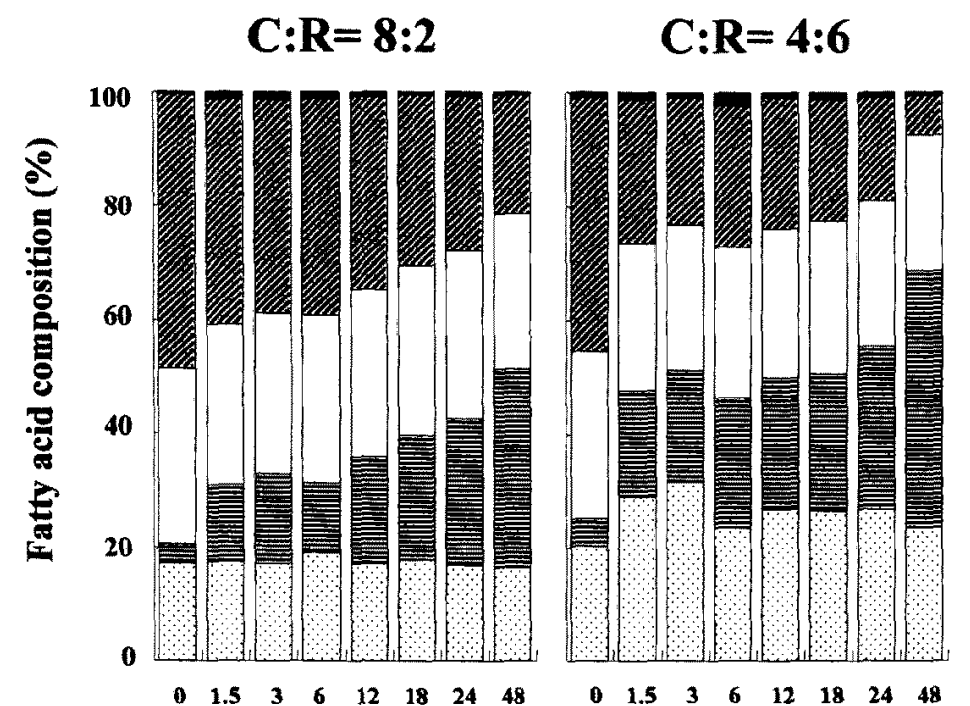

$C: R=0: 10$
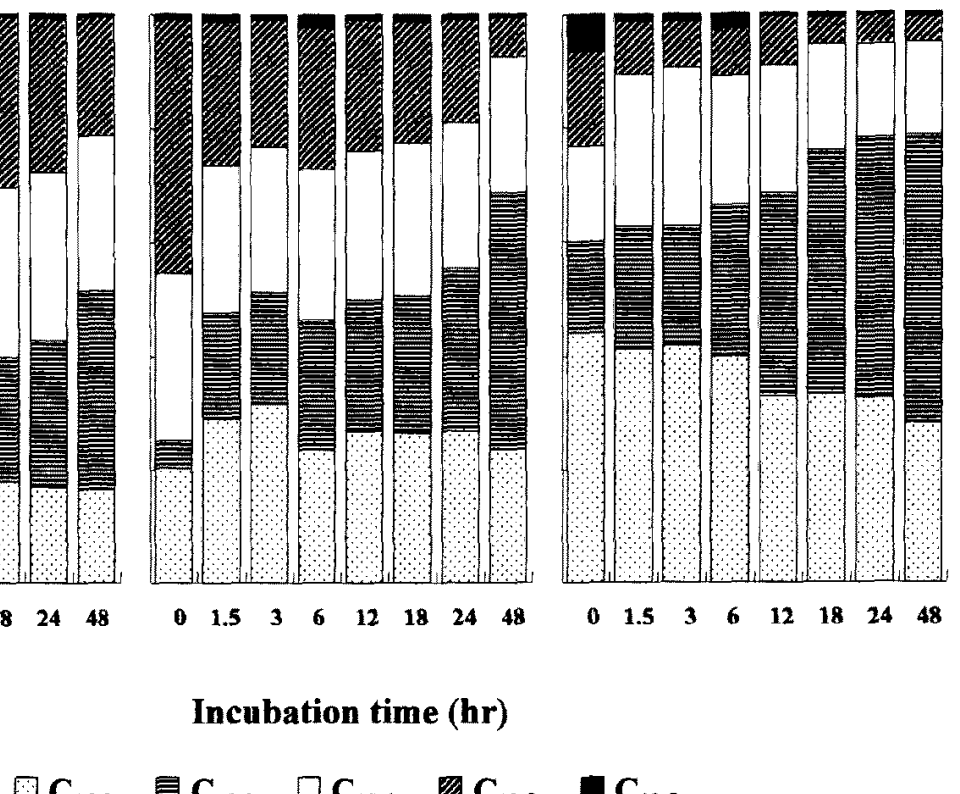

$\square \mathrm{C}_{16: 0} \quad$ 合 $\mathrm{C}_{18: 0} \quad \square \mathrm{C}_{18: 1} \quad \square \mathrm{C}_{18: 2} \quad \square \mathrm{C}_{18: 3}$

Fig. 4. Change in composition of total free fatty acids in residue by nylon bag method with different ratios of concentrate $(C)$ and roughage $(R)$

Differences were significant in diet except $\mathrm{C}_{18: 3}(\mathrm{P}<0.01)$ and time $(\mathrm{P}<0.05)$, not significant in diet $\times$ time $(P \geqq 0.05)$ in all fatty acids.

水素は，打手に粗飼料多給の条件下において，酶酸生成 過程の副産物として生成される ${ }^{10)}$ ，このことを考慮する 之, 飼料元来の $\mathrm{C}_{18: 2}$ が多く含まれ, 粗飼料の給与割合 が高い濃粗比 $4: 6$ と $0: 10$ において，ルーメン内での 水素生成が活発に行われ微生物によるUSFA への水素 添加作用が促進したものと考えられた。また，各脂肪酸 を飼料間でみると， $\mathrm{C}_{18: 0}$ の組成比の平均值（培養 1.5 時 間汃ら 48 時間までの組成比の平均の值；\%) は, 粗飼料 割合の增加にしたがって高く $(\mathbf{P}<0.01), \mathrm{C}_{18: 1}$ と $\mathrm{C}_{18: 2}$ の組成比は, 濃厚飼料割合の増加にしたがって高加った $(\mathbf{P}<0.01)$. Harfoot ら は，インビト口試験において $\mathrm{C}_{18: 2}$ をルーメン内容液に添加したとき， $\mathrm{C}_{18: 2}$ の添加量 が多いほど水素添加作用の中間物質である $\mathrm{C}_{18: 1}$ が蓄積 され，添加量が少ないほよ゙ $\mathrm{C}_{18: 0}$ への変換量が多いこ上 を報告した。 また，Noble ら203は，インビト口試験で ルーメン内容液に $\mathrm{C}_{18: 2}$ を添加したとき, その添加量が 多いはどトランスー11 オクタデセン酸が多量に蓄積する こ上を報告した，本試験では， $\mathrm{C}_{18: 1}$ のシス打よびトラン ス型については測定していないが，上記報告例から，飼 料中に $C_{18: 2}$ を多量に含む曟粗比 $8: 2$ および $4: 60$
TFAにおいて，微生物による水素添加の最終産物とし ての $\mathrm{C}_{18: 0}$ よりる中間物質である $\mathrm{C}_{18: 1}$ が多量に蓄積さ れたことが推察された。 また，さきに筆者らが報告した 濃厚飼料多多給したヒツジのルーメン内液の TFA 組 成 23 上くらべると, ナイロンバック法による培養残渣の ほうが USFAの存在割合が高いことが示される。このこ とは,ルーメン内のUSFA の多くは飼料片に残存するこ 上を示すむのであろう。

図 5 に,ナイロンバック法による飼料の培養残渣の主 要脂肪酸である $\mathrm{C}_{16: 0}$ と $\mathrm{C}_{18}$ の FFA 組成の経時变化を示 した．培養時間による変化では，いずれの飼料でも培養 前と培養 48 時間月とを比較すると, $\mathrm{C}_{16: 0}$ が減少し $(\mathrm{P}<$

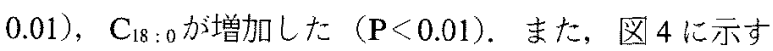
TFA では $\mathrm{C}_{18}$ の USFAに経時的な变化が認められ,

FFA では培養後 TFA 核ど顕著な变化が汪とんどみられ ないことから、いずれの濃粗比です遊離されたUSFA は 即座に微生物により水素添加され, 高度のUSFAはルー メン内の飼料片中に蓄積されないと考えられた，各脂肪 酸を濃粗比間でみると, $\mathrm{C}_{18: 0}$ の組成比の平均值は, 粗飼 料の割合が高いはよ゙増加した $(\mathbf{P}<0.05) 。 \mathrm{C}_{18: 1}$ と $\mathrm{C}_{18: 2}$ 


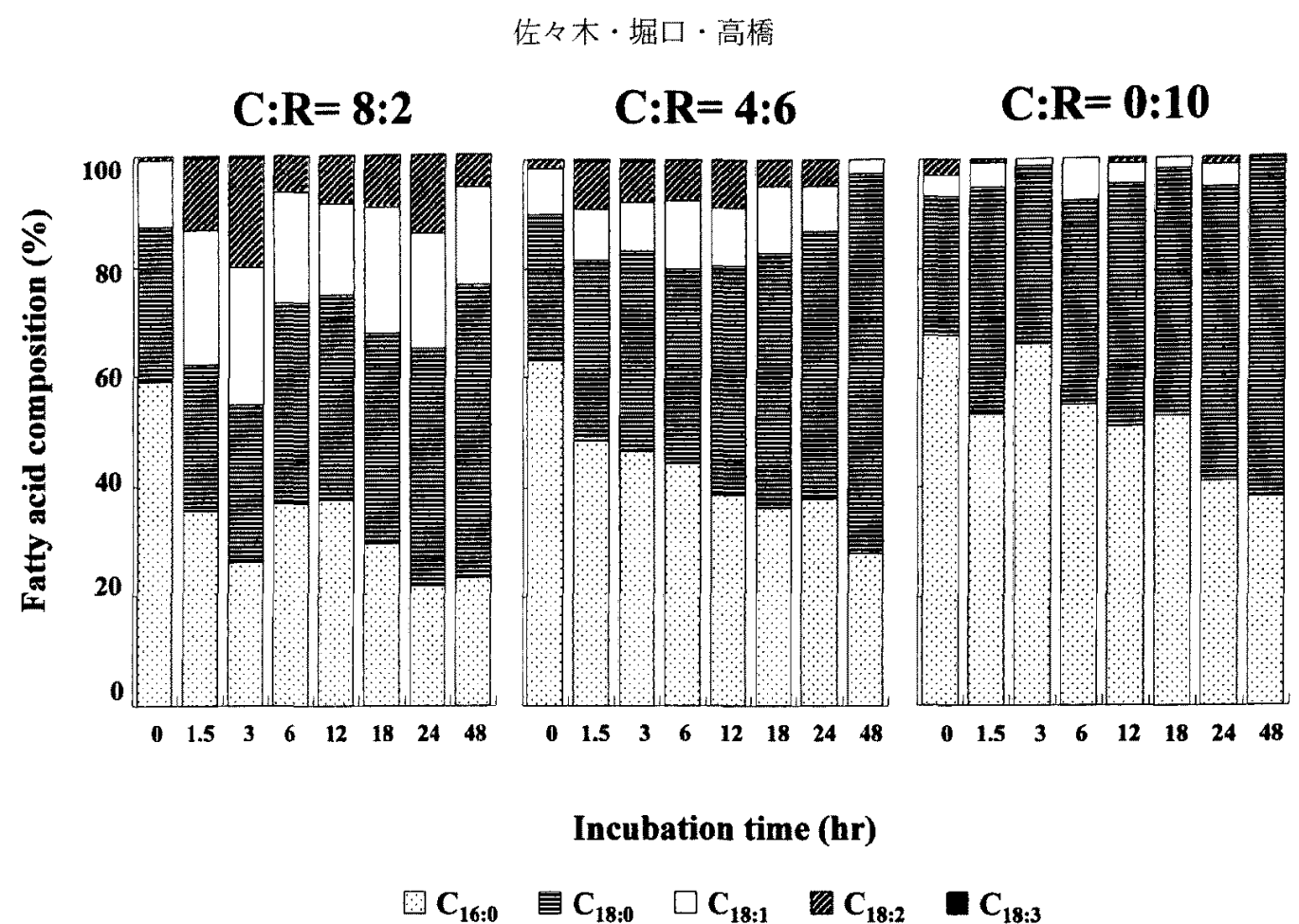

Fig. 5. Change in composition of free fatty acids in residue by nylon bag method with different ratios of concentrate $(C)$ and roughage $(R)$.

Differences were significant in diet except $C_{18: 3}(P<0.05)$ and time of $C_{16: 0}$ and $C_{18: 0}(P<0.05)$, not significant in diet $\times$ time $(\mathrm{P} \geqq 0.05)$ in all fatty acids.

の組成比の平均值は，ともに濃厚飼料の割合を高めるに 之むなって增加し $(\mathrm{P}<0.05), \mathrm{C}_{18 ; 3}$ はいずれの濃粗比で あFFA としてほとんど検出されなかった。また，濃粗 比 $4: 6$ と $0: 10$ の培養 48 時間後に扔いて, 培養残渣に みられる FFA の脂肪酸のほとんどが $\mathrm{C}_{16: 0}$ 上 $\mathrm{C}_{18: 0}$ であ

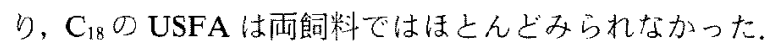
このことは, 濃粗比 4:6お拈よ゙ $0: 10$ に扔いて, 前述し たように酷酸生成時の副産物である水素が多量に産生す ると考えられ，培養残渣に存在する FFAのうち $\mathrm{C}_{18}$ の USFA は水素添加の最終産物である $\mathrm{C}_{18: 0}$ まで即座に变 換されると推察された. Tanaka と Hayashi ${ }^{241}$ は， $\mathrm{C}_{18: 2}$ お よび $\mathrm{C}_{18: 3}$ は，グリセライド分子から分離した侵水素添 加を受けることを報告した。また，Kepler ら ${ }^{13)}$ と Hazlewood と Dawson ${ }^{6)}$ は, 酵秦の特異性から遊離の力 ルボキシル基をす二重結合にのみ水素添加さ机ること を報告した，TFA 組成（図 4) と FFA 組成（図 5) とを 比較すると，わずかながら TFAで $\mathrm{C}_{18: 3}$ がみられるが, FFAではほとんど検出されなかった。このことは，前記 報告を考慮すると，USFAが加水分解された後だだちに 水素添加されると考えられ，トリグリセライドなどの脂
質が加水分解される際，切断されるエステル結合部位の 脂肪酸の二重結合数が多いほど加水分解されやすいと考 えられるが，この機序の解明は今後の課題であろう。

$$
\text { 謝辞 }
$$

本奏験老遂行するに当り，山形大学農学部の荁場猛夫 教授に多大な助言を睗った。ここに記して深甚の謝意を 表する.

\section{文献}

1) Bauchart D, Legay-Carmier F, Doreau M, Gaillard B. Lipid metabolism of liquid-associated and solid-adherent bacteria in rumen contents of dairy cows offered lipidsupplemented diets. British Journal of Nutrition, $63: 563-$ 578. 1990.

2) Folch J, Lees M, Sloan-Stanley GH. A simple method for the isolation and purification of total lipids from animal tissues. Journal of Biological Chemistry, 226:497-509. 1967.

3) Grubb JA, Dehority BA. Effects of an abrupt change in ration from all roughage to high concentrate upon rumen microbial numbers in sheep. Applied Microbiology, 30:404 


\section{ルーメン内飼料中脂肪酸の変化}

$-412.1975$.

4) Harfoot CG, Noble RC, Moore JH. Factors influencing the extent of biohydrogenation of linoleic acid by rumen microorganisms in vitro. Journal of the Science of Food and Agriculture, 24 : 961-970. 1973.

5) Hawke JC. The incorporation of long-chain fatty acids into lipids by rumen bacteria and the effect on biohydrogenation. Biochimica et Biophysica acta, 248: 167-170. 1971.

6) Hazlewood GP, Dawson MC. A phospholipid-deacylating system of bacteria active in a frozen medium. Biochemical Journal. $153: 49-53.1976$.

7) Hespell RB, O'Bryan-Shah PJ. Esterase activities in Butyrivibrio fibrisolvens strains. Applied and Environmental Microbiology, $54: 1917.1988$.

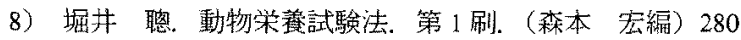
-286. 養賢堂. 東京. 1971.

9）市川伸一・大橋靖雄ＳASによるデー夕解析入阴，第 6 刷. 175-178. 菒京大学出版. 東京. 1990.

10）板橋久雄・佐々木康之. 反感動物の策養生理学. 第 1 刷. （小原嘉昭編）97．農山漁村文化協会．東京１998.

11) Jenkins TC, Palmquist DL. Effect of fatty acids or calcium soap on rumen and total nutrient digestibility of dairy rations. Journal of Dairy Science, 67 : 978-986. 1984.

12) Jenkins TC. Regulation of lipid metabolism in the rumen. Journal of Nutrition, 124 : 1372-1376. 1994.

13) Kepler CR, Tucker WP, Tove SB. Biohydrogenation of unsaturated fatty acids. The Journal of Biological Chemistry, $245: 3612-3620.1970$.

14）古賀照章・阿部 亮. アミラーゼ・ブロテアーゼ混合酵 菜法による細胞壁物質の定輿及び牧乾草・牧草サイレー ジの TDN 含量推定法の検討. 日本草地学会誌, $40: 8-$ 15. 1994 ,

15）倉田陽平・林弥太郎. 動物栄養試験法. 第 1 刷、【森本 宏編）286-297。養賢堂. 東京. 1971.

16) Latham MJ, Sharpe E, Sutton JD. The microbial flora of the rumen of cows fed hay and high cereal rations and its relationship to the rumen fermentation. Journal of Applied Bacteriology, $34: 425-434.1971$.
17) McDonald I. A revised model for the estimation of protein degradability in the rumen. Journal of Agricultural Science, $96: 251-252.1981$.

18) Miettinen H, Huhtanen $\mathbf{P}$. Effect of the ratios of ruminal propionate to butyrate on milk yield and blood metabolites in dairy cows. Journal of Dairy Science, $79: 851-861.1996$.

19）湊 一. 嫌気微生物学: 第 1 版（上本勝司・永井史郎 編）206-218. 養賢堂. 東京. 1993.

20) Noble RC, Moore JH, Harfoot CG. Observations on the pattern on biohydrogenation of esterified and unesterified linoleic acid in the rumen. British Journal of Nutrition, 31 : 99-108. 1974.

21) O'Kelly JC, Spiers WG. Influence of host diet on the concentrations of fatty acids in rumen bacteria from cattle. Australian Journal of Agricultural Research, 42:243-252. 1991.

22) Pitt RE, Van Kessel JS, Fox DG, Pell AN, Barry MC, Van Soest PJ. Prediction of ruminal volatile fatty acids and $\mathrm{pH}$ within the net carbohydrate and protein system. Journal of Animal Science, $74: 226-244.1996$.

23）佐々木啓・高橋敏能・葍場猛夫。 七ッジのルーメン内微 生物扔よび無細胞ルーメン液区分に抢ける長鎖脂肪酸の 量上組成に及济す濃厚飼料之粗飼料の給与割合の影響. 日本畜産学会報, 71：J 26-38. 2000.

24) Tanaka K, Hayashi $H$. The digestion and assimilation of unsaturated fatty acids by ruminant $I$. The breakdown of unsaturated fatty acids in the rumen of goats. The Japanese Journal of Zootechnical Science, $42: 582-592.1971$.

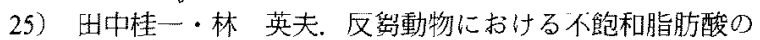
消化拧よび吸収に関する研究I，人工ルーメン内に招け る脂質の加水分解之水素添加, 日本畜産学会報, $43: 20-$ 25. 1972 .

26)田中桂一。第一胃内に拉ける長鎖脂肪酸の代謝につい て. 日本畜産学会報，45:307-318。1974.

27) Visser HDE, Klop A, Meulen JVD, Vuuren AMV. Influence of maturity of grass silage and flaked corn starch on the production and metabolism of volatile fatty acids in dairy cows. Journal of Dairy Science, 81 : 1028-1035. 1998. 
佐々本・堀口・高橋

\title{
Effects of the Different Ratios of Concentrate and Roughage on the Concentration and Composition of Long Chain Fatty Acids in Sheep by Nylon Bag Method
}

\author{
Hiraku SASAKI, Ken-ichi HORIGUCHI ${ }^{1}$ and Toshiyoshi TAKAHASHI ${ }^{1}$ \\ The United Graduate School of Agricultural Science, Twate University, Morioka-shi 020-8550, Japan \\ ${ }^{1}$ Faculty of Agriculture, Yamagata University, Tsuruoka-shi 997-8555, Japan \\ Corresponding : Hiraku SASAKI (fax : +81 (0) 23-623-0790, e-mail : hirari@mc.neweb.ne.jp)
}

The purpose of this study was to investigate the changes of the long chain fatty acids of dietary particles in the rumen in response to the dietary ratios of concentrate $(C)$ and roughage $(R)$. Three sheep fitted with rumen fistula were used to examine the changes of total fatty acids and free fatty acids in the rumen. The diets were divided into $8: 2,4: 6$ and $0: 10 \operatorname{ratios}(\mathrm{C}: \mathrm{R})$. Sheep were fed these three diets once a day. The amount of rations was $2 \%$ body weight as dry matter basis. The diets of concentrate and roughage were differently incubated with nylon bags in the rumen of sheep fed $8: 2$ and $4: 6$ diets, and roughage was incubated with nylon bags in the rumen of sheep fed only roughage. The incubation times were $1.5,3,6,12,18,24$ and $48 \mathrm{~h}$. The residue by incubation were determined for ruminal degradation characteristics, and separated into total fatty acid and free fatty acid. Each fatty acid was determined by gas chromatography. Soluble fraction and insoluble but degradable fraction of ruminal degradation characteristics were high in $8: 2$ and $4: 6(C: R)$ diets $(P<0.05)$. The ratio of free fatty acids to total fatty acids increased with the increase of roughage. The total fatty acids and free fatty acids compositions, oleic acid $\left(\mathrm{C}_{18: 1}\right)$ and linoleic acid increased with the increase of concentrate $(P<0.01)$, and stearic acid $\left(C_{18: 0}\right)$ increased with the increase of roughage $(P$ $<0.01)$. For the composition of free fatty acids in $4: 6$ and $0: 10(\mathrm{C}: \mathrm{R})$ diets, few unsaturated fatty acids of carbon 18 were detected in the residue of $48 \mathrm{~h}$ incubation. Results were assumed that microbial hydrolysis of dietary lipid was accelerated with high ratios of roughage, and that biohydrogenation of free unsaturated fatty acid was accelerated with $4: 6$ and $0: 10(\mathrm{C}: \mathrm{R})$ diets. High ratio of concentrate might cause accumulation of $\mathrm{C}_{18: 1}$ in dietary particle in the rumen.

Animal Science Journal, 71 (9) : J 323-J 330, 2000

Key words : Fatty acids, Concentrate and roughage, Microbial hydrolysis, Biohydrogenation 